\title{
Charles Illouz, Pierre Prétou (dir.), Heur et malheur du joueur : études sur la violence et le Jeu
}

Rennes, Presses Universitaires de Rennes, 2018, 274 p., ISBN: 978-2-7535-6515-9

\section{James Sharpe}

\section{(2) OpenEdition}

\section{Journals}

Édition électronique

URL : https://journals.openedition.org/chs/2954

DOI : $10.4000 /$ chs. 2954

ISSN : 1663-4837

Éditeur

Librairie Droz

\section{Édition imprimée}

Date de publication : 5 août 2021

Pagination : 148-149

ISSN : 1422-0857

\section{Référence électronique}

James Sharpe, «Charles Illouz, Pierre Prétou (dir.), Heur et malheur du joueur : études sur la violence et le Jeu », Crime, Histoire \& Sociétés / Crime, History \& Societies [En ligne], vol. 25, $n^{\circ} 1 \mid$ | 2021, mis en ligne le 05 août 2021, consulté le 09 novembre 2022. URL : http://journals.openedition.org/chs/2954 ; DOI : https://doi.org/10.4000/chs.2954

Ce document a été généré automatiquement le 9 novembre 2022

Tous droits réservés 


\section{Charles Illouz, Pierre Prétou (dir.), Heur et malheur du joueur : études sur la violence et le Jeu}

Rennes, Presses Universitaires de Rennes, 2018, 274 p., ISBN: 978-2-7535-6515-9

James Sharpe

\section{RÉFÉRENCE}

Charles Illouz, Pierre Prétou (dir.), Heur et malheur du joueur : études sur la violence et le Jeu, Rennes, Presses Universitaires de Rennes, 2018, 274 p., ISBN: 978-2-7535-6515-9

Charles Illouz opens his "Prologue" to this collection of essays by claiming that despite two "ouvertures remarquables" on the subject, the issue of play has not received the attention it deserves from the human sciences. The "ouvertures remarquables" are, of course, Johan Huizinga's Homo Ludens, first published in Dutch in 1938, and Roger Caillois: Les Jeux et Les Hommes, published in 1958 and translated into English in 1961 as Man, Play and Games, a reminder, which occasionally has implications for the work under review, that "jeu" can be translated into English by one of two words which have somewhat different, if overlapping, meanings. Although the contributors to this volume are aware of the importance of these two pioneering works, they each set out, in ways that are never less than stimulating, to develop the concept of "play theory" more fully.

2 The variety of approaches offered here is very wide, encompassing varied disciplinary viewpoints, historical periods, and types of "play". Two essays originate from literary studies. Christilla Vasserot focusses on a play by the Cuban writer José Triana, La Noche de los asesinos (The Night of the Assassins), and stresses how it operates as a "play within a play", thus raising a number of theoretical issues. Charles Brion provides an elegant comparison on how Fyodor Dostoevsky in The Gambler and Stefan Zweig in Twenty-four 
Hours in the Life of a Woman portrayed addiction to playing roulette (it will be recalled that Huizinga and Caillois had rather differing interpretations of gambling's status as "play"). Anthropological themes are followed by Roberte Hamayon and Charles Illouz, who focus respectively on the annual games played in Siberia to celebrate the renewal of "la belle saison", and Charles Illouz, who analyses various ludic rituals in Melanesia. The collection's sole contribution from ancient history, Hélène Ménard's "Perdre au jeu dans la Rome antique : du déshonneur à la mort", focusses on the issue, in this case one with potentially serious consequences, of the consequences of losing a game. David le Breton writes on "Jeux de vertige", a difficult term to translate into English, but which signifies playing games, frequently with an individual player taking on fate rather than playing against other people, which involve experiencing a strong and not necessarily comfortable emotion (notably fear and panic, but also possibly ecstasy), if riding a roller coaster constitutes play, this would be an apt example. And Laurent Augier, in his "Jeu fatal et théorie des jeux" examines, via the thinking of Émile Borel and John von Neumann, the "Game Theory" which was influential in the army of the USA immediately after the Second World War, founded attempting to apply mathematical rationality to play, or, for the US Army, to operations research.

Three of the essays presented in this collection touch on themes which will relate more directly to the interests of readers of CHS. Pierre Prétou offers an essay on homicidal brawls arising from play in the kingdom of France in the late middle ages, based on an expert and nuanced reading of Lettres de Grâce involving applications for pardon from the monarch after the incidents in question. Jean-Lucien Sanchez contributes a remarkable opening up of convict life in French Guiana through the study of the Marseillaise, not, in this context, the French national anthem, but rather a game of chance which may have had its origins in a children's game, and was introduced to the penal colony by prisoners from Marseilles. And Mathieu Soula turns to mid eighteenthcentury Toulouse, and to La Compo, an Occitan term which denotes a game played by rival groups of stone-throwing boys, and which introduces the more violent aspects of play. An especially interesting feature of this essay is the way in which the author uses Occitan dictionaries to trace the history and changing definitional nuances of the term.

There is no doubt that this volume demonstrates that play is an important subject and that it can open up wider perspectives on the societies in which it operates. Many readers, however, will find is difficult to discern an overarching theme in so disparate a collection of essays, however scholarly and engaging they may be individually. We have, on the one hand, the Siberian people studied by Hamayon, with their conviction that if their traditional games aren't played, the year will be a bad one, and where the games are an integral part of group identity. And, and on the other hand, we have Dostoyevsky's Alexei Ivanovich's personal woes as he loses at the roulette table. The wellbeing of Russian society in the 1860s and its collective identity did not depend on Ivanovich winning at roulette (although apparently Dostoyevsky wrote the novel in hopes that it would pay off his own gambling debts). But the fact remains that, even if it is asserted that "the play element" can operate outside of normal cultural constraints, the games which flourish in a particular society do tell us something about that society, and sometimes a great deal. And, even outside of the three essays which deal overtly with connections between play and crime, one theme which does recur is that certain types of play, or at least the way in which certain forms of play are, as it were, played, does introduce us to people and practices which are deviant, or at least on the margins of respectable society: gamblers, especially if unsuccessful, would seem to demonstrate 
this point. As Hélène Ménard puts it, "Le jeu, quelle que soit sa forme, peut donc entraîner des comportements qui tombent sous le coup de la loi: rixe, voire sédition, dégradations matérielles, homicide volontaire ou non, pratiques occultes comme avec les tablettes de défixion", these last magical charms employed in hopes of affecting the outcome of chariot races (p. 87). Obviously some of the games played in ancient Rome had potentially unusually high-risk outcomes, but this insight has a more general resonance for historians of crime encountering homo (or indeed femina) ludens.

\section{AUTEURS}

JAMES SHARPE

Department of History

University of York, UK

jim.sharpe[at]york.ac.uken 